\title{
The influence of disease-inducing agents other than Dermatophilus congolensis on
} the severity of bovine dermatophilosis

Oyewusi, I. K., Talabi, A. O., Otesile, E. B. and Oyekunle, M. A.

College of Veterinary Medicine, Federal University of Agriculture, Abeokuta, Nigeria

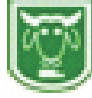

\begin{abstract}
This study was designed to assess the influence of disease-inducing agents other than Dermatophilus congolensis on the incidence of bovine dermatophilosis from cattle farms in Federal University of Agriculture, Abeokuta and Olabisi Onabanjo University, Ogun State and also from Akinyele cattle market in Oyo State. Skin scrapings collected from cattle with typical lesions of dermatophilosis were examined for the presence of bacteria, fungi and ectoparasites. Out of the 57 animals examined with typical skin lesions of dermatophilosis, Dermatophilus congolensis organism was cultured from 23 cases. Other bacterial organisms identified included Staphylococcus aureus (28 cases), Staphylococcus albus (35 cases), Bacillus mycoides (14 cases), Bacillus cereus (1 case), haemolytic Streptococcus (5 cases) Pseudomonas aeruginosa (13 cases), Escherichia coli (16 cases), Proteus spp (4 cases) and Norcardia spp (5 cases). Ticks (mostly Amblyomma variegatum) were seen in all the 57 animals while Demodex bovis, Sarcoptes scabiei var bovis and lice were seen in 15, 4 and 8 cases respectively. It was inferred that secondary bacterial invasions are associated with the pathogenesis and severity of the infection and the presence of ticks and mange mites may serve as the portal of entry for dermatophilosis infection. The control of dermatophilosis should take into account of arthropod vectors and secondary bacterial complications.
\end{abstract}

Keywords: Dermatophilosis, Dermatophilus congolensis, skin parasites, cattle

\section{Introduction}

Dermatophilosis is an acute or chronic exudative dermatitis with wide host range and most commonly affects cattle, sheep and horse (Gebreyohannes and Gebresselassie, 2013). It is caused by Dermatophilus congolensis (Hirsh et al., 2004). The lesions usually appear as tiny scabs or irregularly outlined areas of scabs formed by the coalescence of several tiny scabs (Ojo, 1993). The outer surface of the scab is convex while the inner surface (base) is concave. A pink moist skin surface with granular appearance is exposed on removal of the scab. In Nigeria, the average incidence of the disease is $10 \%$
(10.5 - 12\%) (Oduye, 1976; Abdulkadir, 1989). The disease leads to great economic losses in African countries due to damages of animal hides and skin (Admassu and Alemu, 2011), reduction in milk production (Dalis et al., 2007), poor semen quality (Sekoni, 1993) death and culling (Oduye and Lloyd, 1971; Yereham et al., 2000) and the treatment expenses. One of the most important and economic effects of dermatophilosis on exotic cattle is the restriction which it has imposed on the establishment of high producing exotic cattle and the upgrading of indigenous breeds by cross-breeding with them (Lloyd, 1971). The estimated loss due to 
dermatophilosis in the northern Nigeria, through hide damage, debility and death is US \$30 million annually (Hyslop, 1979). Dermatophilosis is transmitted by direct contact between infected and healthy animals and through indirect contact such as housing or biting arthropods like ticks, Sarcoptes spp mites, Demodex spp mites, stinging and blood sucking flies (Kahn, 2005). Other predisposing factors are high humidity and high rainfall (Radostits et al., 2007). This study describes the possible influence of other disease-inducing agents on the severity and incidence of dermatophilosis in cattle.

\section{Materials and methods}

Skin scab samples were collected from 57 cattle with typical lesions of dermatophilosis into sterile universal bottles for bacteriology and into plain universal bottles for parasitological examinations. The samples were collected from cattle farms in Federal University of Agriculture, Abeokuta and Olabisi Onabanjo University, Ogun State and also from Akinyele cattle market in Oyo State. Bacteriological examination of samples Direct microscopic examination: The underside of some of the scabs were scraped on a glass slide and softened in few drops of distilled water. A smear of the emulsion was made and stained with Giemsa's stain.

Culturing method: The scab samples were rinsed in sterile distilled water and transferred into another tube containing sterile distilled water and left to soften for 3 hours. This was then ground into fine emulsion and transferred into a candle jar for 30-40 minutes. The topmost layer of the emulsion was removed and inoculated onto blood agar for 48 hours. Smears of various colonies of the culture were made and stained with Giemsa for microscopic examination and identification.

Mycological examination: Some of the ground scabs were inoculated onto Sabouraud dextrose Agar plate and examined after 72 hours. Smears of the culture were made and examined under the microscope for identification.

Parasitological examination: The undersides of the scabs collected from each animal were scraped with a scalpel blade into different universal bottles. The skin scrapings were digested with $10 \%$ potassium hydroxide solution to remove the debris and thereafter a pipette drop of the suspension was placed on a slide and covered with a cover slip. The slide was viewed under the microscope at X400 magnification for presence of mites. Ticks collected were identified microscopically.

\section{Results}

Out of the 57 animals examined Dermatophilus congolensis was identified from $23(40.35 \%)$ cases. Other organisms identified were Staphylococcus aureus (49.12\%), Staphylococcus albus (61.40\%), Bacillus mycoides (26.32\%), Bacillus cereus (1.75\%), haemolytic Streptococcus (8.77\%), Pseudomonas aeruginosa (22.81\%), Escherichia coli (28.07\%), Proteus spp (7.02\%), Norcardia spp (8.77\%), Mucor spp (19.30\%), Aspergillus fumigatus (5.26\%), Aspergillus niger (5.26\%) and Penicillium spp (10.53\%). Tick infestations were seen in all the 57 heads of cattle while lice were seen in $14.04 \%$, Demodex bovis in $26.32 \%$ and Sarcoptes scabiei var bovis spp in $7.02 \%$ of the cattle examined (Table 1).

\section{Discussion}

The identification of other diseaseinducing agents may indicate that other bacterial invasions are associated with the pathogenesis and severity of the infection. 
Oyewusi, Talabi, Otesile and Oyekunle

Table 1: Different Organisms in cattle with Dermatophilosis lesions

\begin{tabular}{|c|c|c|c|c|}
\hline $\begin{array}{l}\text { Types of organisms } \\
\text { Identified } \\
\text { cases }\end{array}$ & $\begin{array}{l}\text { Species of the organisms } \\
\text { identified }\end{array}$ & $\begin{array}{l}\text { Number of } \\
\text { positive cases }\end{array}$ & & $\begin{array}{l}\% \text { of } \\
\text { positive }\end{array}$ \\
\hline \multirow[t]{10}{*}{ Bacteria } & D. congolensis & \multicolumn{2}{|l|}{23} & 40.35 \\
\hline & S. aureus & 28 & & 49.12 \\
\hline & S.albus & 35 & & 61.40 \\
\hline & Haemolytic Streptococcus & 5 & & 8.77 \\
\hline & Bacillus mycoides & 14 & & 26.23 \\
\hline & Bacillus cereus & & 1.75 & \\
\hline & Pseudomonas aeruginosa & 13 & & 22.81 \\
\hline & Escherichia coli & & 28.07 & \\
\hline & Proteus spp & 4 & & 7.02 \\
\hline & Norcadia spp & 5 & & 8.77 \\
\hline \multirow[t]{4}{*}{ Fungi } & Mucor sp & 11 & & 19.30 \\
\hline & Aspergillus fumigatus & 3 & & 5.26 \\
\hline & Aspergillus niger & 3 & & 5.26 \\
\hline & Penicillim $s p$ & 6 & & 10.53 \\
\hline \multirow[t]{4}{*}{ Ectoparasites } & Ticks & 57 & & 100.00 \\
\hline & Lice & 8 & & 14.04 \\
\hline & Demodex bovis & & 26.32 & \\
\hline & Sarcoptes scaibei & 4 & & 7.02 \\
\hline
\end{tabular}

This observation supports the finding by Nwufor et al., (1982) who showed that apart from $D$. congolensis, the causative organism, other bacteria species such as Staphylococcus albus, Pseudomonas aeruginosa, and Streptococcus spp. were present in the lesion of dermatophilosis. In a similar study of the bacterial flora of bovine skin infection (Oyekunle, 1985) it was observed that the commonest organism associated with dermatophilosis was Staphylococci. Staphylococcus albus, Ps eudomonas aeruginosa and Streptococcus spp have been suggested to be responsible for the extensive suppuration and severe toxaemia characteristic of chronic dermatophilosis (Nwufor et al., 1982). None of the fungi isolated from dermatophilosis lesion could be said to be pathogenic; they are opportunistic fungi. The probability of exposure of some of the sampled cattle to previous unsuccessful and prolonged antibiotic treatment could not be ruled out (Kahn, 2005). This is because it has been established that the exposure of animals to prolonged administration of antimicrobial compounds or immunosuppressive substances may increase the likelihood of infection by opportunistic fungi such as Mucor spp, Aspergillus spp and Penicillium spp (Kahn, 2005). In addition, opportunistic fungi usually require a host that is debilitated (as in dermatophilosis cases) or immunosuppressed to establish infection.

The presence of ticks in all the infected animals is very significant. It agrees with the findings of Morrow et al., (1993) that the occurrence of dermatophilosis on cattle in the tropics is closely associated with infestation by Amblyomma variegatum 
ticks (Kassaye et al., 2003). In tropical areas ticks promote severe infection in cattle by suppression of immune function (Radostits et al., 2007). Mange mites were also seen in $33.33 \%$ of the infected animals examined. These mites cause skin eruption and damage to hides and skins of cattle thereby creating the portal of entry for Dermatophilus congolensis. This result supports the report of Oduye (1976) that the disease can be associated with demodectic mange infestation in cattle.

It can therefore be concluded from the study that for a successful control of dermatophilosis, the predisposing and secondary factors of the disease must well be taken care of.

\section{References}

Abdulkadir, I. A. 1989. Infectious disease of livestock in Nigeria: An outline. Ahmadu Bello University Press Limited, Zaria, Nigeria; $37-40$

Admassu, M. and Alemu, S. 2011. Study on clinical bovine dermatophilosis and its potential risk factors in Northwestern Ethiopia. International Journal of Animal and Veterinary Advances 3(1): 33-36.

Dalis, J. S., Kazeem, H. M., Makinde, A. A. and Fatihu, M. Y. 2007. Agalactia due to severe generalized dermatophilosis in a white Fulani cow in Zaria, Nigeria. Vom Journal of Veterinary Science 1(4): 56-58.

Gebreyohannes, M. and Gebresselassie, M. 2013. An overview on Dermatophilosis of animals: a review. Journal of Animal Science Advancement. 3 (7):337-344.

Hirsh, D.C., Maclachlan, N.J. and Walker, R.L. 2004. Veterinary Microbiology. $2^{\text {nd }}$ edition. Published by Blackwell Publishing Company. pp 220-221.
Hyslop, N. S. 1979. Dermatophilosis (Streptothricosis) in animals and man. Comp. Immunol. Microbiol. Infect. Dis. 2:389-404.

Kahn, C.M. 2005. The Merck Veterinary Manual $9^{\text {th }}$ ed. USA: Merck and Co. Inc. Pp510-692.

Kassaye, E., Moser, I. and Woldemeskel, M. 2003. Epidemiological study on clinical bovine dermatophilosis in Northern Ethiopia. Deutsche Tierarztliche Wochenschrift. 110: 422-425.

Lloyd, D. H. 1971. West Africa: Bovine Streptothricosis. Span. 14, 170. Cited by Zaria, T. (1993). Dermatophilus congolensis infection in animals and man: An update. Comp. Immun. Microbiol. Infect. Dis. 16(3) 179-222.

Morrow, A. N., Arnott, J. L., Heron, I. D., Koney, E. B. M. and Walker, A. R. 1993. The effects of tick control on the prevalence of dermatophilosis on indigenous cattle in Ghana. Revue d'Elevage el de Medecine Veterinaire des Pays Tropieaux, 46:317-322.

Nwufor, K. J., Amakiri, S.F. and Ojo M. O. 1982. Skin bacteria flora of Friesian cattle with advanced infection of cutaneous Streptothricosis in Nigeria. Bull. Anim. Health Prod. Africa. 30:265 267

Oduye, O. O. 1976. Bovine streptothricosis in Nigeria. In: Dermatophilus infection in Animals and Man. Edited by D. H. Lloyd and K. C. Sellers Academic Press, London, Pp 2-116.

Oduye, O. O. and Lloyd, D. H. 1971. Incidence of bovine cutaneous streptothricosis in Nigeria. Br. Vet. J., 127: 505-510.

Ojo, M.A. 1993. Manual of Pathogenic Bacteria. $1^{\text {st }}$ ed. Shaneson C. I. 
Limited. Pp 76-81.

Oyekunle, M. A. 1985. Studies on the bacterial flora of skin infection in cattle. M. Sc. Thesis, University of Ibadan.

Radostits, O. M., Gray, C. C., Hinchcliff, K. W. and Constable, P.G. 2007. Veterinary Medicine. In: A Text book of the Diseases of Cattle, Horses, Sheep. Pigs and Goats; $10^{\text {th }}$ ed. W.B. Saunders Company. Philadelphia: $1048-1051$.

Sekoni, V.O. 1993. Effects of severe chronic scrotal Dermatophilus congolensis (kirchi) infection on semen characteristics in Zebu/Friesian crossbred bulls and effect of long-acting terramycin chemotherapy. Theriogenology, 40 (1): 211-223.

Yereham, I., Elad, D. and Perl, S. 2000. Economic aspects of outbreaks of dermatophilosis in first-calving cows in nine herds of dairy cattle in Israel. Vet. Rec. 146(24): 695-698.

Received: $7^{\text {th }}$ April, 2014

Accepted: 25 ${ }^{\text {th }}$ June, 2014 